\title{
FAMILIA CREŞTINĂ ŞI EDUCAŢIA TINERILOR. PROVOCĂRI ŞI ŞANSE
}

\author{
Gavril Trifa*
}

\begin{abstract}
The year 2016 was declared by the Holy Synod of the Romanian Orthodox Church as "the solemn year of the religious education of the Orthodox Christian youth", which is meant to emphasize young people's education and their steering towards assuming such everlasting values as those represented by Family, Church, and School. Before talking about fundamental institutions (family, church, school), we must mention the fact that God is an eternal factor and source of education, He is the "Alpha and Omega" of the pedagogical act. God not only created heaven and earth, but he also founded both the family and the Church. Education is not an exclusively human act or effort, but the result of divine and human synergy. In other words, it is a theandric act. Those who tried to "educate" without God failed miserably. The oldest and strongest human institution is the family, the epitome of creation and an expression of love and of providential communion with God. The family has often been called "the little church", or "the domestic church" because of its community aspect and the atmosphere of holiness it must cultivate.
\end{abstract}

Keywords: education, family, church, school, youth.

\section{Iubirea, fundament al familiei şi al educaţiei creştine}

Iubirea constituie virtutea centrală a creştinismului, iar educaţia matricea prin care aceasta poate să devină o realitate pentru persoană şi pentru Biserică (Matei 28, 19-20). Din iubirea Sa desăvârşită, Dumnezeu a creat lumea, a mântuit-o prin Iisus Hristos, îi poartă de grijă şi o sfinţeşte neîncetat prin Duhul Sfânt. Această iubire divină intratrinitară fundamentează iubirea omului faţă de semeni. În această relaţie de iubire desăvârşită este implicată cunoaşterea reciprocă a celor două persoane: „Precum eu îl cunosc, prin iubire, mai bine poate decât se cunoaşte el însuşi, aşa şi el, prin

\footnotetext{
* PhD, Assistant Professor, Faculty of Orthodox Theology, West University of Timişoara, Romania.
} 
iubirea cu care se apropie de mine, mă poate cunoaşte mai bine decât mă cunosc eu însumi"'

Cel ce nu iubeşte n-a cunoscut pe Dumnezeu, pentru că Dumnezeu este iubire (I Ioan 4, 7-8). Sfântul Ioan Hrisostom descrie iubirea absolută a Dumnezeului întrupat pentru oameni, pornind de la valoarea smereniei şi a prieteniei:

„Eu sunt un tată pentru voi, spune Hristos, şi un frate, un mire şi un cămin, un infirmier şi un veşmânt, o rădăcină şi piatra din capul unghiului. Eu sunt pentru voi tot ce vă puteţi dori. Dorinţa Mea este ca voi să nu duceţi lipsă de nimic. Eu vă voi sluji; pentru că nu am venit ca să fiu slujit, ci ca să slujesc. Eu vă sunt un prieten şi un mădular al trupului şi capul trupului, un frate, o soră şi o mamă. Eu sunt totul pentru voi. Este de ajuns să rămâneţi în comuniune cu Mine. Pentru voi, M-am făcut sărac, pentru voi am fost un pelerin în această lume, pentru voi am fost răstignit pe cruce şi am fost pus în mormânt"2.

Temelie şi condiţie a familiei, iubirea este în acelaşi timp şi un scop al acesteia. Prin iubire soţul şi soţia se angajează în refacerea unităţii primordiale a omului. Legătura dintre iubirea divină intratrinitară şi iubirea din cadrul familiei creştine rezultă din însăşi caracterul de Taină al Căsătoriei, care nu este altceva decât „un eveniment ce manifestă şi împlineşte adevărul şi viaţa ei (a Bisericii, n.n.), o realitate transfigurând natura fragmentată şi preschimbând-o într-o imagine a comuniunii treimice"3. Părintele Dumitru Stăniloae arată că Dumnezeu, în unitatea Lui fiinţială tripersonală, este model pentru familia creştină şi oglindă a educaţiei realizate în lumina Cuvântului:

„În Ortodoxie Dumnezeu e o fiinţă în trei persoane, adică o strânsă intimitate între trei eu, o viaţă comună între trei subiecte. Nici unitatea

\footnotetext{
${ }^{1}$ Dumitru Belu, Despre iubire, apud. Pr. Ioan C. Teşu, Din iadul patimilor spre raiul virtuţilor, Bucureşti, Editura Christiana, 2000, nota 474, p. 155.

${ }^{2}$ Pr. Ioannis Chryssavgis, Iubire, căsătorie şi sexualitate, în vol. „Bioetica şi taina persoanei”, Bucureşti, Editura Bizantină, 2006, p. 95-96.

${ }^{3}$ Christos Yannaras, Libertatea moralei, Bucureşti, Editura Anastasia, 2002, p. 164.
} 
nu e sfâş̧iată, nici persoanele nu se contopesc. Nici indivizi izolaţi şi egoişti, nici masă în care persoanele sunt înăbuşite. Ci unire familială; în familie e un suflet, un gând, o voinţă. (...) În Dumnezeu e o ideală viaţă familială, plină de iubire: nu fără rost o persoană serveşte Tată şi alta Fiu"4.

Se creează, astfel, premisele comuniunii între membrii familiei, prin mijlocirea Fiului: „Una dintre primele consecinţe ale asemănării căsătoriei cu Sfânta Treime, «structură a supremei iubiri», o constituie faptul că ea însăşi apare ca o «mică împărăţie», o microbasilea. Ecclesia trinitară se oglindeşte în ecclesia domestică. Ceea ce face ca chipul Treimii să devină chipul căsătoriei e o anumită înrâurire a persoanelor divine în viaţa soţilor şi, în primul rând, o prezenţă şi o intervenţie a persoanei Fiului. Trecerea de la comuniunea divină la comuniunea umană se face în Hristos, consubstanţial cu Tatăl şi cu Duhul în divinitatea Sa, consubstanţial nouă în unitatea Sa..."5.

Iubirea este sentimentul firesc al celor doi soţi, o realitate cu caracter de angajament pentru o cale comună în viaţă, dar şi un dar de la Dumnezeu primit în Taina cea mare a Cununiei. Această iubire din cadrul familiei trebuie cultivată şi susţinută printr-un efort neîncetat. Ea presupune delicateţe, responsabilitate şi respect şi prin ea fiecare iese în întâmpinarea celuilalt. Relaţia dintre cei doi soţi, astfel înţeleasă şi cultivată, poate să devină o icoană a iubirii trinitare: „Atunci când iubirea conjugală nu deschide cuplul către o perspectivă mai presus de el însuşi, atunci când relaţia celor doi în cadrul căsătoriei nu reflectă relaţia din cadrul Sfintei Treimi, atunci când iubirea cuplului nu se lărgeşte într-un mod sau altul, iubirea conjugală, din icoana care este chemată să fie, se reduce la un simplu idol"6.

${ }^{4}$ Dumitru Stăniloae, Ortodoxie şi românism, Bucureşti, Editura Albatros, 1998, p. 58.

${ }^{5}$ Ilie Moldovan, Iubirea, taina căsătoriei. Teologia iubirii I, Alba Iulia, Editura Reîntregirea, 1996, p. 18-19.

${ }^{6}$ Ioannis Chryssavgis, Iubire, căsătorie şi sexualitate..., p. 100. 
În cadrul familiei creştine, soţii alcătuiesc o unitate împreună cu Dumnezeu, aşa cum arată Părintele Alexander Schmemann: „Întro căsătorie creştină, de fapt, cei căsătoriţi sunt trei; şi loialitatea celor doi faţă de cel de al treilea, care este Dumnezeu, îi păstrează pe cei doi într-o unitate activă între ei, şi cu Dumnezeu"7. Sentimentul iubirii, întărit de binecuvântarea divină a Cununiei, este acela care-i uneşte tainic pe soţi, aşa cum afirmă Sf. Chiril al Alexandriei: „Puţin importă dacă soţul nu se uneşte trupeşte şi psihologiceşte cu cea carei este soţie, după lege. Căci o dată pentru totdeauna au devenit un singur trup şi, într-un fel, un singur suflet, iubirea legându-i strâns şi

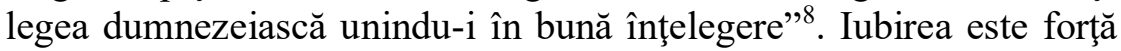
dătătoare de viaţă, temelia familiei, iar familia este o pecete a iubirii „taina iubirii”, cum o defineşte Sfầntul Ioan Gură de Aur. În familie, iubirea este izvorul de energie fizică şi spirituală a celor doi soţi, prin care este desfiinţată izolarea şi se realizează o împărtăşire integrală de existenţă şi viaţă. Iubirea devine calea prin care omul se îmbogăţeşte interior, iar în iubire nu este frică, căci ,cel ce se teme nu este deplin în iubire" (I Ioan 4,18).

\section{Familia şi educaţia viitorului adult}

Problema calităţii educaţiei din familie şi impactul acesteia asupra dezvoltării ulterioare a copilului constituie o preocupare importantă a teologiei din primele veacuri creştine. Mărgăritar al literaturii creştine de sec. II-III, lucrarea „Pedagogul”, care conţine o sinteză a ideilor educaţionale ale epocii, a fost adresată celor care ,au urmat Cântăreţului Hristos şi s-au născut din nou [...]. Pedagogul acestor nou-născuţi îi creşte, îi educă, le dă reguli de purtare; îi învaţă cum să mănânce, cum să bea, cum să se poarte la ospeţe, cum să râdă, cum să doarmă, cum să se îmbrace, cum să se încalţe, cum să se

\footnotetext{
7 Alexander Schmemann, Pentru viaţa lumii - Sacramentele şi Ortodoxia, Bucureşti, Editura Institutului Biblic şi de Misiune al Bisericii Ortodoxe Române, 2001, p. 111.

8 Sf. Chril al Alexandriei, Comentariu la Profetul Maleahi, apud Georges Habra, Iubire şi senzualitate, Bucureşti, Editura Anastasia, 1994, p. 85.
} 
folosească de podoabe, parfumuri şi coroane, cum să se poarte soţii între ei"”.

Teologia contemporană, pe fondul modificărilor structurale pe care le aduce implicarea tot mai redusă a părinţilor în educaţia moral-religioasă a copiilor semnalează faptul că

„imaginea bună pe care o avem despre noi, cum că suntem încă nişte părinţi foarte apropiaţi şi grijulii faţă de propriii copii, se pierde sub tuşele din ce în ce mai groase pe care realitatea ni le impune. Nu mai suntem - aşa cum spuneau până mai ieri sociologii - printre puţinele societăţi ce funcţionează după structura familiei tradiţionale, în care scopul esenţial al familiei îl reprezenta copilul, ci tindem să ne integrăm rapid societăţii de tip post-consum, unde relaţia părinte-copil nu este primordială, iar valori ca dezvoltarea personală sau propriul sentiment de satisfacţie devin mai importante decât copilul. Dincolo de aceste caracteristici ce ţin de analiza specializată atât a tipului social de familie, cât şi a gradului de preluare de către societate a unor funcţii şi responsabilităţi ale familiei, ne aflăm în dezarmanta situaţie de a constata că nu ştim cum să facem faţă unui fenomen" ${ }^{\prime 0}$.

Sfântul Ioan Gură de Aur menţiona în opera despre creşterea copiilor că răul nu poate fi îndreptat din lume deoarece niciun om nu are grijă de copii ${ }^{11}$. Un copil nu are nevoie de valori materiale, ci de un bun pedagog, care îl poate forma şi educa ${ }^{12}$. Acelaşi sfânt îi ruga pe creştini ca, înainte de toate celelalte, să le ofere copiilor „o bună

9 Dumitru Fecioru, Introducere, în „Pedagogul”, P.S.B., nr. 4, Bucureşti, Editura Institutului Biblic şi de Misiune al Bisericii Ortodoxe Române, 1982, p. 15.

${ }^{10}$ Vasile Crețu, Probleme actuale ale pastorației tinerilor în Biserica Ortodoxă Română, în V. Mândâcanu, I. Scheau, D. Opriş (ed.), „Educaţia umanistă în perspectiva triadei: pedagogie-filosofie-teologie", Chişinău, Editura Pontos, 2011, p. 87.

${ }^{9}$ Sfântul Ioan Gură de Aur, Despre feciorie. Apologia vieţii monahale. Despre creşterea copiilor, Bucureşti, Editura Institutul Biblic şi de Misiune al Bisericii Ortodoxe Române, 2001, p. 162.

${ }^{12}$ Vasile Creţu, Educaţia religioasă a copiilor în opera Sfântului Ioan Gură de Aur, în O. Moşin, I. Scheau, D. Opriş (ed.), „Educaţia din perspectiva valorilor. Tom VII: Summa Theologiae”, Bucureşti, Editura Eikon, 2015, p. 204. 
educaţie. Dacă îţi iubeşti copilul, arat-o prin educaţia ce i-o dai"13. Copilul, având sufletul fraged, îşi va întipări învăţăturile cele bune ale părinţilor ca sigiliul aplicat pe ceară. Întărindu-se astfel şi crescând, nimeni nu-i va putea desprinde educaţia pe care a primit-o în sânul familiei. Totodată, sufletul unui copil este ca o icoană, iar părinţii sunt pictorii. Aceştia trebuie să lucreze cu multă grijă şi exactitate pentru desăvârşirea icoanelor lui Dumnezeu.

Părinţii, ca primi pedagogi, sunt chemaţi să-şi înveţe copiii să fie cumpătaţi, să privegheze, să se roage cu stăruinţă, dar mai ales să alunge din sufletul lor desfrânarea, căci această patimă tulbură cel mai tare sufletelor tinerilor. Nepăsarea faţă de formarea duhovnicească a tinerilor este o atitudine foarte des întâlnită printre părinţi. Planurile lor pentru viitorul copiilor se limitează, în general, la reuşita în viaţă din punct de vedere profesional şi la bunăstare. Prin această grijă primordială, copiilor li se introduce în suflet doi mari tirani: iubirea de argint şi iubirea de slavă. Tinerii devin astfel materialişti şi plini de slavă deşartă, stricarea lor datorându-se exclusiv acestei goane după bunuri materiale. Iar în strânsă legătură cu aceste două patimi este desfrânarea, sau pofta trupului, care mutilează atât trupul, cât mai ales sufletul tânărului.

Sfântul Ioan Gură de Aur mai spunea că sufletul unui copil este un oraş de curând zidit ${ }^{14}$, ale cărui porţi sunt ochii, limba, auzul, mirosul şi pipăitul. Prin aceste porţi gândurile strică sau desăvârşesc sufletul copilului. Limba trebuie să fie întrebuinţată la rostirea cuvintelor cuviincioase, evlavioase, la rostirea cuvântului lui Dumnezeu. Sfầntul îi îndeamnă pe părinţi să pună lege copiilor lor, ca să nu ocărască şi să nu hulească pe nimeni, să nu înjure, să nu se bată cu nimeni, să fie blânzi şi îngăduitori. Auzul să fie, de asemenea, supravegheat pentru ca pruncului să nu-i fie dat să audă basme prosteşti şi băbeşti, bârfe, vorbe josnice sau cântece lumeşti, ci cuvântul lui Dumnezeu, povestiri ziditoare de suflet sau psalmi şi vieţi de sfinţi. Mirosul are rostul de a respira aerul. De aceea Sfântul

\footnotetext{
${ }^{10}$ Sfântul Ioan Gură de Aur, Despre feciorie. Apologia vieţii monahale. Despre creşterea copiilor..., p. 163.

${ }^{14}$ Ibidem, pag. 164.
} 
spune că „nimic nu nimiceşte atât vigoarea sufletului cât mirosirea parfumurilor." Văzul este greu de păzit deoarece prin ochi, se pot deştepta în sufletul copilului tot felul de pofte. Astfel, această poartă poate fi păzită prin încântarea adusă de lucrurile create de Dumnezeu. Dacă ochiul este obişnuit cu frumusețea cerului, a stelelor, a florilor, a naturii şi mai ales a icoanelor, îşi va întoarce privirea cu dezgust de la lucrurile de prisos. Iar a cincea poartă, pipăitul, poate fi protejată prin înlăturarea luxului (haine, aşternuturi moi), care moleşeşte sufletul prin impresia pe care o transmite de la suprafaţă.

\section{Educaţ̧ia copiilor şi armonia familiei}

Educaţia copiilor în cadrul familiei se realizează prin jertfă, este marea cruce a familiei. „Educaţia copiilor în familie necesită multă dragoste, dăruire de sine şi jertfă, fiind o lucrare mai însemnată decât naşterea trupească a acestora" ${ }^{15}$. Orice acţiune educativă trebuie să ţină cont de puterile fizice şi spirituale ale copiilor şi de capacitatea acestora de a asimila informaţia de factură religioasă. În acest sens se poate face o paralelă cu educaţia făcută de Dumnezeu cu oamenii până la primele scrieri biblice: „scripturile nu ni s-au dat de la început, pentru ca omul să fie învăţat mai întâi din lucrurile naturii şi nu din cele ale literelor" ${ }^{\prime 1}$. Educaţia trebuie să înceapă de la o vârstă fragedă, pentru ca lucrurile care devin obişnuinţă la aceea vârstă să devină lege la adolescenţă $\breve{a}^{17}$. În scrierile Sfântului Ioan Gură de Aur se observă că, pe lângă o serie de factorii externi, există şi factori interni, sădiţi de Dumnezeu în sufletele noastre. Cel mai important factor intern este conştiinţa, „una dintre cărţile ce ne conduc la cunoaşterea adevărului; ea îşi ridică glasul din adâncul

\footnotetext{
${ }^{15}$ Pastorala Sf. Sinod Al B.O.R. Cu Prilejul Anului Omagial al Sf. Botez şi al Sf. Cununii în Patriarhia Română.

${ }^{16}$ Sfântul Ioan Gură de Aur, La Efeseni, Omilia 21, PG. 62, p. 161.

${ }_{17}$ Teofan Mada, Familia creştină la Sfântul Ioan Gură de Aur, Sibiu, Editura Agnos, 2008, p. 106.
} 
sufletului şi ne spune ce trebuie să facem"18. Iar ca factori externi avem: familia, şcoala, Biserica şi societatea ${ }^{19}$.

Cea mai veche şi, totodată, cea mai puternică instituţie umană este familia, cunună a creaţiei şi expresie a iubirii şi comuniunii proniatoare a lui Dumnezeu. Ea a fost numită adesea „mica biserică”, sau „biserica de acasă”, pentru caracterul ei comunitar şi atmosfera de sfinţenie pe care trebuie s-o cultive ${ }^{20}$. În familie, copilul învaţă ce înseamnă dragostea părintească, învaţă să vorbească, învaţă să se roage, învaţă credinţa în Dumnezeu şi tot aici în cadrul familiei deprinde adevărurile religioase ${ }^{21}$. Sfântul Ioan Gură de Aur ne spune că a fi părinte nu este de ajuns numai să dai naştere, ci trebuie să dai şi educaţie ${ }^{22}$. Dumnezeu pune în sufletul părinţilor dragoste pentru copiii lor, pentru ca să devină şi ei educatorii lor spre virtute. „Dumnezeu face ca mama nu numai să zămislească, ci şi să dea chip frumos copiilor prin educaţie". ${ }^{23}$ Pentru ca un copil să fie educat în adevăratul sens al cuvântului este necesar ca legătura dintre soţi în cadrul familiei să fie una specială, după modelul celei dintre Hristos şi Biserică: „Aşadar, cum Biserica se supune lui Hristos, adică bărbaţi şi femei, la fel şi voi femei, supuneţi-vă bărbaţilor ca şi lui Dumnezeu. Bărbaţi, iubiţi pe femeile voastre aşa cum şi Hristos a iubit Biserica!"24. Deci, iată, în cadrul unei familii trebuie să existe o legătură puternică de dragoste şi de jertfă între bărbat şi femeie. Această legătură puternică, această armonie trebuie să se păstreze cu orice preţ şi să creeze un climat favorabil pentru că numai aceasta

\footnotetext{
18 Mihail Bulacu, Noblețea educaţiei copiilor după Sfântul Ioan Hrisostom, Bucureşti, 1940, p. 13.

19 Monica Opriş, Religie, morală, educaţie. Perspective teologice şi pedagogice, Bucureşti, Editura Basilica, 2011, p. 78-85.

${ }^{20}$ Vasile Gordon, Catehetica Ortodoxă, Curs pentru anul al III - lea - Teologie Pastorală, Bucureşti, 2003, p. 109.

${ }^{21}$ Constantinia Iorda, Educaţia preşcolarilor după principiile Sfântului Ioan Gură de Aur, Bucureşti, Editura Sophia, 2009, p. 56.

${ }^{22}$ Sfântul Ioan Gură de Aur, $P G$ 54, p. 636.

${ }^{23}$ Ioan Gh. Coman, Frumusetile iubirii de oameni în spiritualitatea patristică, Timişoara, Editura Mitropoliei Banatului, 1988, p. 66.

${ }^{24}$ Sfântul Ioan Gură de Aur, PG. 62, p. 136.
} 
face ca familia să devină un izvor de bucurii şi de susţinere a întregii familii.

Înfăptuirea educaţiei creştine nu se poate realiza fără un climat pedagogic şi psihologic potrivit la care fiecare trebuie să contribuie la menţinerea dragostei şi a păcii. Soţii trebuie să se iubească, să se ajute reciproc, căci iubirea dintre aceştia este ceea ce face conducerea netiranică şi ascultarea plăcută ${ }^{25}$. Sfântul Ioan Gură de Aur promovează şi vorbeşte despre unitatea familiei ca despre unitatea dintre trup şi suflet, vorbind că în cadrul unei astfel de unităţi este de neînţeles conflictul între soţii ${ }^{26}$. De altfel, familia este comparată de Sfântul Părinte cu o corabie: „Cearta femeii cu a bărbatului seamănă cu disputa dintre comandant şi cârmaci; în clipa în care corabia este în pericol să se scufunde neînţelegerea părinţilor influenţează negativ toţi membrii familiei” ${ }^{27}$. „Când comandanţii fac răzmeriță participă şi călătorii şi este firesc în consecinţă să se scufunde corabia împreună cu echipajul. Astfel şi aici, când bărbatul şi femeia se află în neînţelegere, este firesc să participe la relele urmări şi ceilalţi membrii ai familiei”, ne spune sfântul ${ }^{28}$.

Pentru antichitatea creştină ${ }^{29}$, în special, mediul familial este prezentat drept factorul de maximă importanţă pentru dezvoltarea sufletească şi morală a copiilor. Aceasta deoarece copilul îl imită pe părinte, copilul imită atmosfera văzută în familia lui. Prin urmare, poate să încerce să urmeze şi „virtutea părinţilor”. Dar totuşi nu trebuie să se înţeleagă că acest caracter religios al părinţilor se transmite automat la copii. Copiii pot imita liber comportamentul părinţilor, pot să se folosească de virtutea lor. „Părinţii, prin viaţa lor armonioasă şi liniştită, creează mediul natural de neînlocuit pentru

5 Marin Stamate, Educaţia creştină în opera Sfântului Ioan Gură de Aur, Galaţi, Editura Episcopiei Dunării de Jos, 2003, p. 49.

${ }^{26}$ Sfântul Ioan Gură de Aur, $P G .54$, p. 416-417.

${ }^{27}$ Constantinia Iorda, Educaţia preşcolarilor după principiile Sfântului Ioan Gură de Aur..., p. 59.

${ }^{28}$ Sfântul Ioan Gură de Aur, PG. 61, p. 153.

29 Dorin Opriş, Christian antiquity and the origins of modern education, Proceedings of ICERI2015 Conference, Seville, Spain, pp. 1196-1198. 
înfăptuirea fericită a educaţiei religioase a copilului şi dezvoltarea conştiinţei lui religioase" ${ }^{\text {"30 }}$.

Această educaţie a părinţilor este asemănată de Sfântul Ioan Gură de Aur cu migala pictorilor şi a sculptorilor: „Daţi-vă osteneala ca să construiţi lui Dumnezeu minunate statui; îndepărtaţi ce este de prisos şi adăugaţi ce lipseşte. În fiecare zi uitaţi-vă cu grijă la ei; observaţi şi darul pe care-1 au de la natură, spre a-l dezvolta, dar şi cusurul de la natură, spre a-1 îndepărta" ${ }^{31}$. „Aşadar fiecare dintre voi, taţi şi mame, astfel să vă îngrijiţi de aceste minunate statui, precum îi vedem pe pictorii şi sculptorii care îşi desăvârşesc icoanele şi statuile cu multă precizie. Căci pictorii, punându-şi în faţă tabloul în fiecare zi, aplică pe el culoarea care trebuie. Şi cioplitorii în piatră, la fel, şi ei o lucrează pe aceasta, îndepărtând ce e de prisos şi adăugând ce trebuie" ${ }^{32}$.

Copilul nu trebuie format numai la vârsta preşcolară, ci pe parcursul întregii vieţi. Astfel Sfântul Ioan Gură de Aur îndeamnă părintele să-şi supravegheze copilul, această supraveghere fiind o obligaţie morală a părinţilor ${ }^{33}$, neîndeplinirea acesteia fiind $o$ consecinţă de neiertat, pentru că cei care sunt educaţi trebuie să fie educaţi în perspectiva devenirii atleţi ai lui Hristos ${ }^{34}$.

Sfântul Ioan Gură de Aur atrage atenţia părinţilor care nu-şi îndeplinesc datoria de educator în familie, asemănându-i cu nişte criminali: „părinţii care nu se ocupă cu educaţia copiilor sunt mai criminali decât omorâtorii propriilor lor copii. Este mai mică nelegiuirea să împlânţi sabia în grumazul tânărului, decât să-i corupi şi să-i pierzi sufletul. Învierea viitoare va repara moartea corporală,

${ }^{30}$ Constantinia Iorda, Educaţia preşcolarilor după principiile Sfântului Ioan Gură de Aur..., p. 60.

${ }^{31}$ Dumitru Fecioru, Ideile pedagogice ale Sfântului Ioan Gură de Aur, în rev. „Biserica Ortodoxă Romană”, LV (1937), nr. 7-10, p. 461.

32 Sfântul Ioan Gură de Aur, Despre slava deşartă, Bucureşti, Editura IBMBOR, 2001, p. 98.

${ }^{33}$ Constantinia Iorda, Educaţia preşcolarilor după principiile Sfântului Ioan Gură de Aur..., p. 61.

${ }^{34}$ Ibidem. 
dar pentru moartea sufletului nu va fi nici un leac" ${ }^{35}$. Sfântul Ioan Gură de Aur prezintă şi modelul de atitudine a părinţilor faţă de copii lor atunci când aceştia fac lucruri greşite. În primul rând el ne recomandă înăbuşirea furiei, apoi îngăduinţa şi în cele din urmă iertarea $^{36}$, scopul final fiind educarea acestora pentru etapele ulterioare ale vieţii în care suferinţa se cere asumată $\breve{a}^{37}$.

\section{Membrii familiei şi rolul lor în educaţia copiilor}

Educaţia poate fi definită drept suma de idei, modele şi acţiuni prin care omul este îndrumat să îşi descopere calităţile şi sensul vieţii, iar apoi să trăiască în comuniune cu aceste valori primordiale $^{38}$. Educaţia creştină a copiilor revine ambilor părinţi, dar Sfântul Ioan Gură de Aur îi atribuie principala responsabilitate tatălui $^{39}$. Tatăl trebuie să armonizeze voinţa copiilor prin sfaturi, îndemnuri, prin cuvinte aceasta fiind stabilită de către Însuşi Dumnezeu. Pentru a argumenta rolul tatălui în susţinerea în familie a modelului religios-moral evanghelic, Sfầntul Ioan Gură de Aur apelează la tradiţia iudaică potrivit căreia tatăl era administratorul familiei. Comentând Epistola I către Corinteni, ne spune că nimeni nu poate să conducă o comunitate eclesiastică decât acela care-şi dovedeşte capacitatea de administrare a casei lui. Deci iată că responsabilitatea tatălui pentru mântuire este echivalentă cu responsabilitatea unui preot care trebuie să-şi conducă turma către Hristos $^{40}$.

${ }^{35}$ Dumitru Fecioru, Ideile pedagogice ale Sfântului Ioan Gură de Aur..., p. 455.

${ }^{36}$ Constantinia Iorda, Educaţia preşcolarilor după principiile Sfântului Ioan Gură de Aur..., p. 62.

${ }^{37}$ Dorin Opriş, Monica Opriş, Teenagers'models of understanding suffering, în „European Journal of Science and Theology”, 8/2012 (2), p. 173-175.

${ }^{38}$ Panayotis Nellas, Ortodoxia - divino-umanism în acţiune, trad. de pr. Ioan Ică Sr., Ed. Deisis, Sibiu, 2013, p. 271.

${ }^{39}$ Sfântul Ioan Gură de Aur, $P G$ 62, p. 388.

${ }^{40}$ Constantinia Iorda, Educaţia preşcolarilor după principiile Sfântului Ioan Gură de Aur..., p. 62. 
Din punct de vedere pedagogic, prezenţa tatălui şi intervenţia în viaţa de familie este de neînlocuit, pentru că numai astfel tatăl poate să cunoască exact slăbiciunile membrilor familiei şi în acest sens, în acest fel poate să le corecteze ${ }^{41}$. Pentru a oferi o educaţie corectă, tatăl trebuie să dea dovadă de două lucruri: de dragoste pentru copii lui, dar şi de tactul pedagogic pe care Dumnezeu i 1-a sădit în suflet: „Dumnezeu ţi-a dat copiii, spune Sfântul Ioan, ca ei să învețe virtutea de la tine. Căci de aceea a vrut ca să unească astfel neamul oamenilor, făcând cele două lucruri foarte mari: unul, aşezându-i învăţători pe taţi, al doilea, sădind în ei multă dragoste" ${ }^{42}$.

Autenticitatea dragostei tatălui faţă de copii se dovedeşte, ne spune Sfântul Ioan, şi prin încurajarea pe care acesta o face copiilor în realizarea lucrurilor de folos, dar şi în susținerea copiilor în încercările acestora de a realiza lucruri mai grele ${ }^{43}$. Dacă Sfầntul părinte laudă tații care îşi fac datoria în familie, pe cei care nu se îngrijesc de educaţia copiilor îi critică socotindu-i nedemni de numele de tată pentru că educaţia copiilor constituie o necesitate în viaţa Bisericii şi în viaţa societăţii ${ }^{44}$.

Buna creştere a copiilor, în viziunea Sfântului Ioan Gură de Aur, reprezintă principala îndeletnicire a mamei ${ }^{45}$. Aceasta pentru că mama are privilegiul de a fi mai mult timp decât tatăl în sânul familiei. Inima unei mame este înzestrată de Dumnezeu să fie mai aproape de sufletul copilului ${ }^{46}$ însă lucrarea aceasta de bună creştere a copiilor se realizează numai atunci când mama foloseşte dragostea adevărată pentru copii ei. Sfântul vorbeşte şi subliniază răsplata oferită de Dumnezeu pentru efortul depus de mamă, astfel el ne spune

\footnotetext{
${ }^{41}$ Sfântul Ioan Gură de Aur, $P G 51$, p. 100.

${ }^{42}$ Idem, PG 62, 459.

${ }^{43}$ Constantinia Iorda, Educaţia preşcolarilor după principiile Sfântului Ioan Gură de Aur..., p. 64.

${ }^{44}$ Sfântul Ioan Gură de Aur, $P G$ 47, p. 363.

${ }^{45}$ Idem, PG 51, 231.

${ }^{46}$ Marin Stamate, Educaţia creştină în opera Sfântului Ioan Gură de Aur..., p. 52.
} 
„căci nu eşti zguduită atât de mult de dureri şi de chinuri cât câştigi dacă vrei, din creşterea copiilor, primind pretext de reuşite. Căci copiii pe care i-ai născut, dacă se bucură de îngrijirea cuvenită şi sunt duşi spre virtute de grija ta, devin motiv şi pretext de multă mântuire pentru tine şi pentru reuşite proprii, şi alături de ei vei primi multă preţuire a îngrijirii... dacă îi duci pe aceştia, dacă rogi, dacă înveţi, dacă sfătuieşti, multă răsplată a acestei griji îţi va fi pusă deoparte de Dumnezeu" ${ }^{47}$.

Această grijă deosebită a mamei pentru copii se explică prin faptul că bărbatul este de multe ori ocupat cu călătoriile, cu grijile societăţii, însă mamele fiind acasă se pot îngriji de buna creştere a copiilor ${ }^{48}$. Însă ca o mamă să-şi poată realiza acest lucru şi să-şi crească copii conform învăţăturii creştine trebuie să fie ea însăşi lumina, trebuie să fie ea însăşi un model, un exemplu pentru copii: „Când o mamă este dotată cu înţelepciune şi viaţă curată, când e profund virtuoasă şi devotată soţului prin legătura dragostei, ea reuşeşte să facă din el un auxiliar de nădejde în educaţia copiilor" ${ }^{\text {" }}$.

Sfântul Ioan evidenţiază rolul mamei în educaţia fetelor. Aceasta trebuie să înceapă de când copiii sunt încă mici ${ }^{50}$, pentru că numai ele se pot apropia mai uşor de sufletul fetelor şi le pot îndrepta, le pot învăţa care sunt adevăratele valori morale. Îndepărtarea de lux constituie elementul principal la Sfântul Ioan Gură de Aur când vorbeşte despre educaţia fetelor: „Însă important este aici că acest mod de educaţie va trebui să aibă punctul de plecare în prima vârsta a copilăriei" ${ }^{51}$. Mama trebuie să-şi educe fiica să fie gospodină, însă înainte de toate să fie evlavioasă, neiubitoare de averi şi cuviincioasă ${ }^{52}$.

\footnotetext{
${ }^{47}$ Sfântul Ioan Gură de Aur, $P G 54$, p. 637.

${ }^{48}$ Idem, PG 54, p. 638.

${ }^{49}$ Marin Stamate, Educaţia creştină în opera Sfântului Ioan Gură de Aur..., p. 53.

${ }^{50}$ Teofan Mada, Familia creştină la Sfântul Ioan Gură de Aur..., p. 113.

${ }^{51}$ Constantinia Iorda, Educaţia preşcolarilor după principiile Sfântului Ioan Gură de Aur..., p. 69.

${ }^{52}$ Sfântul Ioan Gură de Aur, $P G$ 62, p. 371.
} 


\section{Divorţul, marea criză a familiei şi a educaţiei creştine. Proiect de cercetare}

Preliminarii: Problematica divorţului devine tot mai prioritară în societatea contemporană, dată fiind rata tot mai ridicată de divorţuri, fenomen care se acutizează şi în România, iar implicaţiile sunt din ce în ce mai mari, inclusiv în spaţiul educaţional laic ${ }^{53}$. Considerăm că demersurile venite inclusiv din spaţiul bisericesc nu au avut rezultatele scontate, din mai multe motive, printre care: insuficienta adaptare a discursului teologic la aşteptările tinerilor de azi; limitarea cercetărilor privind cauzele divorţurilor tot mai numeroase la analiza documentelor, fără demararea unor cercetări în colaborare cu sociologi, psihologi, pedagogi sau medici; lipsa unor materiale catehetice relevante pentru actuala generaţie de tineri; slaba consecvenţă în aplicarea pe termen mediu şi lung a unor demersuri legat de diminuarea ratei divorţurilor.

I. Scopul proiectului de cercetare: diminuarea ratei divorţurilor la familiile tinere

\section{Obiective:}

1. realizarea unei mai bune cateheze premaritale şi post maritale, pe grupe de vârstă, particularităţi sociale şi culturale

2. constituirea unui mecanism funcţional de susţinere duhovnicească a tinerilor aflaţi în iminenţă de divorţ

III. Demersuri de cercetare:

1. Analiza bibliografică pe baza textelor biblice, patristice şi de literatură laică

53 Cercetările noastre arată faptul că în învăţământul preuniversitar românesc fiecare clasă include între 7\%-12\% elevi din familii disfuncţionale, cu părinţii divorţaţi sau separaţi temporar, ceea ce face adesea dificilă atingerea finalităţilor de ordin formativ ale disciplinei religie. 
2. Identificarea prin metode sociologice a modelelor morale pe baza cărora tinerii elevi şi studenţi, inclusiv din mediul teologic se raportează la căsătorie şi viaţa de familie

3. Evidenţierea pe baza unei analize de context a modelelor de succes prin care preoţii reuşesc să-i determine pe tineri să renunţe la acţiunea de divorţ

IV. Lucrări şi materiale catehetice elaborate pentru atingerea obiectivelor proiectului:

1. Realizarea unui volum colectiv cuprinzând problematici privind familia, naşterea de copii şi divorţul, din perspectiva diferitelor discipline teologice, raportat la particularităţile societăţii actuale [util în realizarea materialelor elaborate în cadrul proiectului şi în abordarea diferitelor teme teologice, la seminariile teologice şi la facultăţile de teologie]

2. Realizarea unui scurt ghid (pliant) privind întemeierea familiei în lumina Evangheliei şi câteva aspecte legate de Taina Cununiei, pe care viitorii miri să-1 primească înainte/imediat după ce au luat decizia de a se căsătorii, de la preotul paroh sau duhovnic [realizat împreună cu profesorii de teologie şi cu preoţi, duhovnici, aşa încât să beneficieze de un amplu grad de acceptare şi utilizare în parohii]

3. Realizarea unui îndreptar privind viaţa creştină de familie, pe care cei doi miri să-1 primească de la preotul oficiant, imediat după săvârşirea Tainei Cununiei [cu o extensiune apropiată de cel primit de la Primărie, după cununia civilă]

4. Realizarea unui document de lucru pentru elevii de liceu şi pentru profesorii de religie, care să poată fi valorificat la diferite teme din programa şcolară sau în alte activităţi educative şi catehetice [cu o abordare pe nivelul de înţelegere al acestora a principalelor teme privind pregătirea unui creştin în perspectiva întemeierii în lumina evangheliei a familiei]

\section{Activităţi şi cursuri de formare:}

- realizarea de întâlniri ale profesorilor de teologie cu preoţii, pentru a stabili un model unitar şi cât mai larg acceptat de abordare în context universitar şi parohial a problemelor privind întemeierea 
familiei şi viaţa religios-morală a familiei creştine ortodoxe, în raport cu particularităţile societăţii actuale

- întâlniri cu tineri elevi şi studenţi, pentru a-i pregăti pe aceştia spre a putea să-şi susţină prietenii sau colegii care se află în pragul divorţului

- realizarea unor cursuri de formare cu profesorii de religie, legat de abordarea în diferite contexte sociale şi culturale a problemelor privind familia creştină

- pregătirea specială a unui număr de preoţi şi duhovnici pentru a putea să-i susţină mai eficient pe tinerii aflaţi în pragul divorţului

\section{În loc de concluzii}

Dumnezeu, în nemărginita Sa iubire, a creat lumina, soarele, luna şi stelele, apa şi uscatul, plantele, peştii şi animalele. Totul era numai energie, numai viaţă. Lipsea totuşi cineva. Lipsea „raţiunea”, fiinţa conştientă, care să soarbă în suflet toate aceste frumuseţi, care să le înţeleagă şi care mai apoi să se ridice pe aripile rugăciunii la Acela care a făcut toate acestea. Ideea perfectă de „om” a apărut în momentul când Dumnezeu a creat primul bărbat şi prima femeie, amândouă fiinţe perfecte în sine, dar cu particularităţi specifice fiecărui sex. Cele două sexe sunt menite să fie nedespărţite şi tocmai de aceea a aşezat Creatorul pe prima femeie lângă primul bărbat şi a format prima familie la începutul lumii. Aşa cum păcatul a pătruns păcatul în lume şi prin păcat moartea, planul lui Dumnezeu, sfânt şi tainic, a făcut din educaţie, începând cu chiar prima poruncă creşteţi şi vă înmulţiţi - calea desăvârşită pe care a lăsat-o oamenilor spre a duce mai departe opera Sa creatoare. Dacă păcatul originar a putut avea repercusiuni atât de dramatice pentru om şi pentru întreaga lume, calea de ieşire din sfera morţii spirituale, după Răscumpărare, este calea educaţiei, începând cu cea din familie, fundament şi reper pentru devenirea oricărei persoane. 


\section{Bibliografie}

1. Bulacu, Pr. Mihail, Nobleţea educaţiei copiilor după Sfântul Ioan Hrisostom, Bucureşti, 1940.

2. Chryssavgis, Pr. Ioannis, Iubire, căsătorie şi sexualitate, în vol. „Bioetica şi taina persoanei”, Bucureşti, Editura Bizantină, 2006.

3. Coman, Pr. Prof. Ioan Gh., Frumusetile iubirii de oameni în spiritualitatea patristică, Timişoara, Editura Mitropoliei Banatului, 1988.

4. Creţu, Pr.lect.univ.dr. Vasile, Probleme actuale ale pastoraţiei tinerilor în Biserica Ortodoxă Română, în Virgil Mândâcanu, Ioan Scheau, Dorin Opriş (ed.), „Educaţia umanistă în perspectiva triadei: pedagogie-filosofieteologie", Chişinău, Editura Pontos, 2011, p. 87.

5. Creţu, Pr.lect.univ.dr. Vasile, Educaţia religioasă a copiilor în opera Sfântului Ioan Gură de Aur, în O. Moşin, I. Scheau, D. Opriş, D. (ed.), „Educaţia din perspectiva valorilor. Tom VII: Summa Theologiae", Bucureşti, Editura Eikon, 2015, p. 204.

6. Fecioru, Pr. Dumitru, Ideile pedagogice ale Sfântului Ioan Gură de Aur, în rev. „Biserica Ortodoxă Romană”, LV (1937), nr. 7-10.

7. Fecioru, Pr. Dumitru, Introducere, în „Pedagogul”, P.S.B., nr. 4, Bucureşti, Editura Institutului Biblic şi de Misiune al Bisericii Ortodoxe Române, 1982.

8. Gordon, Pr. Prof. Dr. Vasile, Catehetica Ortodoxă, Curs pentru anul al III lea - Teologie Pastorală, Bucureşti, 2003.

9. Habra, Georges, Iubire şi senzualitate, Bucureşti, Editura Anastasia, 1994.

10. Iorda, Constantinia, Educaţia preşcolarilor după principiile Sfântului Ioan Gură de Aur, Bucureşti, Editura Sophia, 2009.

11. Mada, Ieromonah Teofan, Familia creştină la Sfântul Ioan Gură de Aur, Sibiu, Editura Agnos, 2008.

12. Moldovan, Pr. Prof. Ilie, Iubirea, taina căsătoriei. Teologia iubirii I, Alba Iulia, Editura Reîntregirea, 1996.

13. Nellas, Panayotis, Ortodoxia - divino-umanism in acţiune, trad. de pr. Ioan Ică Sr., Ed. Deisis, Sibiu, 2013, p. 271.

14. Opriş, D., Opriş, M., Teenagers'models of understanding suffering, în „European Journal of Science and Theology”, 8/2012 (2).

15. Opriş, Dorin, Christian antiquity and the origins of modern education, Proceedings of ICERI2015 Conference, Seville, Spain, pp. 1196-1198.

16. Opriş, Monica, Religie, morală, educaţie. Perspective teologice şi pedagogice, Bucureşti, Editura Basilica, 2011.

17. Schmemann, Pr. Prof. Alexander, Pentru viaţa lumii - Sacramentele şi Ortodoxia, Bucureşti, Editura Institutului Biblic şi de Misiune al Bisericii Ortodoxe Române, 2001. 
18. Sfântul Ioan Gură de Aur, Despre feciorie. Apologia vieţii monahale. Despre creşterea copiilor, Bucureşti, Editura Institutul Biblic şi de Misiune al Bisericii Ortodoxe Române, 2001.

19. Sfântul Ioan Gură de Aur, Despre slava deşartă, Bucureşti, Editura Institutului Biblic şi de Misiune al Bisericii Ortodoxe Române, 2001.

20. Stamate, Pr. Lec. Dr. Marin, Educaţia creştină în opera Sfântului Ioan Gură de Aur, Galaţi, Editura Episcopiei Dunării de Jos, 2003.

21. Stăniloae, Pr. prof. dr. Dumitru, Ortodoxie şi românism, Bucureşti, Editura Albatros, 1998.

22. Teşu, Pr. Ioan C., Din iadul patimilor spre raiul virtuţilor, Bucureşti, Editura Christiana, 2000.

23. Yannaras, Christos, Libertatea moralei, Bucureşti, Editura Anastasia, 2002. 